\title{
A comparison of the resistance of Temporary Edge Protection Systems to static and dynamic loads
}

\section{Comparación del comportamiento de sistemas provisionales de protección de borde frente a cargas estáticas y de impacto}

M. N. González ${ }^{(*)}, \underline{\text { A. Cobo }}^{(*)}$, A. Castaño ${ }^{(*)}$, M. I. Prieto ${ }^{(*)}$

\section{ABSTRACT}

Temporary Edge Protection Systems (TEPS) are designed to withstand the impact of a worker that walks, stumbles, and falls against them. This is by nature a dynamic action; however, many standards evaluate TEPS when the surface or slope is slightly inclined (less than $10^{\circ}$ ), applying static requirements. The performance requirements demanded by these standards are assumed to be equivalent to the impact of a worker, however this point has not been tested. In this study, TEPS with tubular steel guardrails and wooden boards of different quality under two types of loads are evaluated using the static requirements detailed in standard EN 13374. TEPS are subjected to an impact energy of $180 \mathrm{~J}$, simulating a worker of $90 \mathrm{~kg}$ walking at a speed of $2 \mathrm{~m} / \mathrm{s}$. The results demonstrate that the static requirements of EN 13374 are more demanding than the impact of $180 \mathrm{~J}$ in all the systems under study.

Keywords: Safety guardrails; flexural strength; deformation; static load; impact.

\section{RESUMEN}

Los sistemas provisionales de protección de borde (SPPB) están diseñados para detener el impacto de un trabajador que camina, tropieza y golpea contra ellas. Esto supone una acción de naturaleza dinámica. Sin embargo, muchas normas evalúan SPPB utilizando requisitos de tipo estático cuando la superficie de trabajo está poco inclinada (menos de $10^{\circ}$ ) suponiendo que equivalen al impacto de un trabajador. No obstante, este aspecto no se ha confirmado experimentalmente. En este trabajo SPPB con barandillas de tubos de acero y de tablas de madera se han evaluado usando los requisitos estáticos definidos por la norma EN 13374. Posteriormente, se han sometido a una energía de impacto de $180 \mathrm{~J}$, que simula a un trabajador de $90 \mathrm{~kg}$ caminando a una velocidad de $2 \mathrm{~m} / \mathrm{s}$. Los resultados demuestran que los requisitos estáticos de la norma EN 13374 son más exigentes que el impacto de $180 \mathrm{~J}$ en todos los sistemas estudiados.

Palabras clave: Barandillas de seguridad; resistencia a flexión; deformación; carga estática; impacto.

(*) Escuela Técnica Superior de Edificación - Universidad Politécnica de Madrid (España).

Persona de contacto/Corresponding author: alfonso.cobo@upm.es (A. Cobo)

Cómo citar este artículo/Citation: González, M. N., Cobo, A., Castaño, A., Prieto, M.I . (2015). A comparison of the resistance of Temporary Edge Protection Systems to static and dynamic loads. Informes de la Construcción, 67(538): eo85, doi: http://dx.doi.org/10.3989/ic.13.161.

Licencia/License: Salvo indicación contraria, todos los contenidos de la edición electrónica de Informes de la Construcción se distribuyen bajo una licencia de uso y distribución Creative Commons Reconocimiento no Comercial 3.o. España (cc-by-nc). 


\section{INTRODUCTION AND OBJECTIVES}

Construction accidents due to falls from height imply a high percentage of total accidents in the sector (1) (2) (3). International standards and regulations limit falls from height in order to prevent injuries and harm to workers (4) (5) (6) (7).

Protection against falls from height through Temporary Edge Protection Systems (TEPS) constitute an effective system, because they eliminate the on-site risk, preventing the fall and thereby avoiding the possibility of injury to the worker that impacts against another system that only limits falls from height. Prior studies have shown that the appropriate use of TEPS can prevent a large number of accidents and falls from height (8) (9) (10) (11) (12). Other studies have evaluated the performance of TEPS against static loads and impacts (13) (14) (15) (16) (17) (18).

The norms that regulate TEPS that were consulted (19) (20) (21) (22) (23) require these systems to fulfill both geometric and mechanical standards. The geometric requirements establish the dimensions of the TEPS so that it constrains the worker from falling outside the system and prevents objects from falling from the structure into space. The requirements of a mechanical type mean that the systems should have a certain resistance and they limit its movement in reaction to a given load. The objective of establishing a maximum deflection limit is based on preventing the worker from losing balance on the TEPS and falling into space (24).

One of the fundamental purposes of a TEPS is to stop a worker walking on the structure from stumbling, falling, and hitting the TEPS. This is by nature a dynamic action that involves an impact. There are also norms that specify dynamic loads for TEPS testing, which model the shock of a worker against a TEPS by means of an impact at a particular level of energy. The test method of the Institut Nacional de Recherche et de Sécurité (25) (24) indicates an impact of a body of $80 \mathrm{~kg}$ of mass that strikes at a speed of $2 \mathrm{~m} / \mathrm{s}(\mathrm{E}=160 \mathrm{~J})$. Other norms (26) specify an impact with a mass of $90 \mathrm{~kg}$ at the aforementioned speed $(\mathrm{E}=180 \mathrm{~J})$.

Standard EN 13374 (19) classifies the TEPS into three classes (A, B and C), in accordance with the inclination of the work surface and the height of the fall of the person that is to be protected.

The class A systems, which are the most widely employed, can only be used when the slope of the work surface is below $10^{\circ}$. Equivalent low static loads are evaluated. The systems are classified in classes B and C for slopes over the structure, evaluation of which requires the use of dynamic loads applied in the form of an impact.

Evaluation of class A systems by means of static loads as per EN 13374 or the use of actions of a static nature from other standards implies, as commented on earlier, that the static loads specified in these standards should be equivalent to impact loads that the TEPS should withstand in the case of real accidents. However, no analytical or experimental works have been found to support such a statement.

This work is intended to determine whether the use of equivalent static load systems that are specified in the standards imply that the impact of a worker when falling and hitting a TEPS will be absorbed.

A dynamic load, equivalent to an energy impact of $180 \mathrm{~J}$ was used to achieve this objective. Equivalent static loads were used as per standard EN 13374. The TEPS were tested with vertical tubular steel posts attached either to wooden or to tubular steel guardrails of circular section, using both static loads and dynamic impacts for subsequent comparison of the results.

\section{SYSTEMS THAT WERE TESTED}

Seven TEPS were analyzed with spans between the vertical posts of $2400 \mathrm{~mm}$ and a height of $1000 \mathrm{~mm}$, measured from the reference level to the upper edge of the main guardrail. The vertical post in all the systems consisted of a tubular section of $\mathrm{S} 235$ steel with a diameter of $40 \mathrm{~mm}$ and a thickness of $1.5 \mathrm{~mm}$ (40·1.5). The retaining lugs of the vertical posts were $S 275$ steel.

Two systems were prepared with circular tubular S 235 steel rails with sections of $25 \cdot 1.5(\mathrm{~S} 1)$ and of $40 \cdot 1.5(\mathrm{~S} 2)$.

Five TEPS were prepared with pinewood guardrails supplied by Aserradero from El Espinar, Segovia (Spain). The wooden boards for the 5 systems had a rectangular section of $150 \mathrm{~mm}$ in height. Systems $\mathrm{S}_{3}$ and $\mathrm{S}_{4}$ were formed by $22 \mathrm{~mm}$ thick boards, while the boards in systems $\mathrm{S}_{5}, \mathrm{~S} 6$ and $\mathrm{S}_{7}$ had a thickness of $27 \mathrm{~mm}$. The wooden boards with a thickness of $27 \mathrm{~mm}$ had the following visual classifications ME1 with a resistant class of C27; ME2 with a resistant class of $\mathrm{C} 18$; and the Visual Defect class (R). Visual classification ME1 and Visual Defect $\mathrm{R}$, were used for the $22 \mathrm{~mm}$ thick boards. The visual classification and the resistance classes of the wooden boards used in the test are those used in UNE 56544 (27).

The performance of the vertical posts (P1) in these systems was compared with other vertical posts also tubular, but with a section of $30 \cdot 1.5(\mathrm{P} 2)$. $\mathrm{P} 1$ and $\mathrm{P} 2$ were tested independently of complete systems.

The geometric characteristics of the sections of the seven test systems and the vertical posts together with the visual classification and strength of the wooden tables are indicated in Table 1.

The seven systems were anchored to a reinforced concrete beam into which PVC tubes had been embedded to house the circular section vertical posts. As an example, Figure 1 shows the layout and the geometric characteristics of test system 1.

Table 1. Geometric characteristics and resistance of the sections of the seven systems and vertical posts.

\begin{tabular}{|c|c|c|c|c|c|c|c|c|c|}
\hline & \multicolumn{2}{|c|}{ STEEL } & \multicolumn{5}{|c|}{ WOOD } & \multicolumn{2}{|c|}{ VERTICAL POSTS } \\
\hline & S1 & S2 & S3 & S4 & S5 & S6 & $\mathbf{S}_{7}$ & P1 & P2 \\
\hline SECTION & $25 \cdot 1.5$ & $40 \cdot 1.5$ & $150 X 22$ & $150 X 22$ & $150 X 27$ & $150 X 27$ & $150 \times 27$ & $40 \cdot 1.5$ & $30 \cdot 1.5$ \\
\hline VISUAL & - & - & ME1 & $\mathrm{R}$ & ME1 & $\mathrm{ME} 2$ & $\mathrm{R}$ & - & - \\
\hline RESISTANCE & S235 & $\mathrm{S} 235$ & $\mathrm{C} 27$ & - & $\mathrm{C} 27$ & $\mathrm{C} 18$ & - & $\mathrm{S} 235$ & $\mathrm{~S} 235$ \\
\hline
\end{tabular}




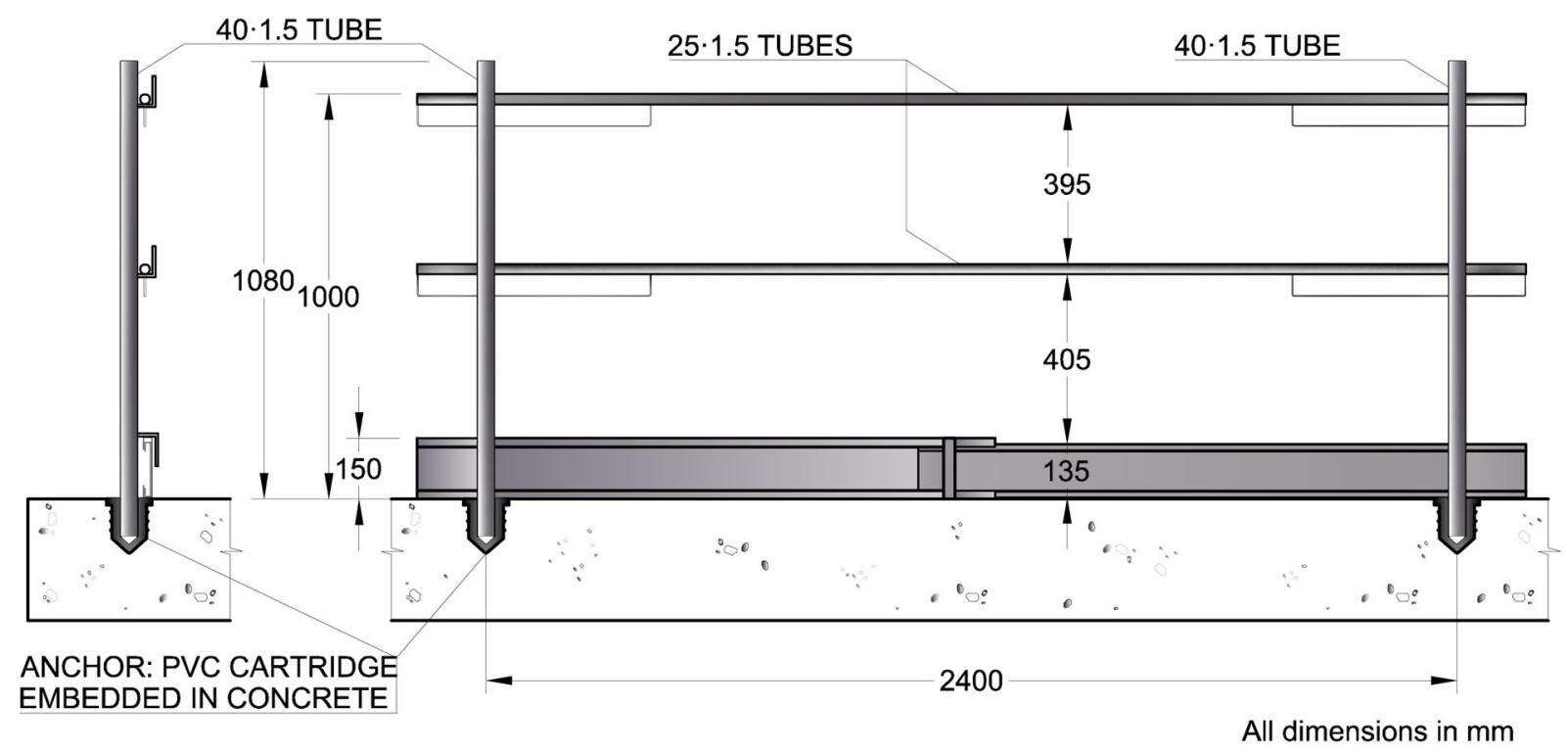

Figure 1. Geometry of system 1.

\section{TECHNIQUES EMPLOYED}

\subsection{Static tests}

The assessment of TEPS under static loads was performed as per standard $\mathrm{EN}-13374$, analyzing three critical situations: Ultimate Limit State with fundamental load (ULS), Serviceability Limit State (SLS) and Ultimate Limit State with Accidental Load (AL). Moving beyond any one of these situations implies that $E_{d} \leq R_{d}$, where $E_{d}$ is the result of calculating the effect of the actions and $R_{d}$ is the corresponding calculation of the resistance.

The ULS test confirms that the rails and vertical post should be designed to withstand a load of $0.30 \mathrm{kN}$ applied perpendicularly to the plane of the system at the weakest points. For the assessment of this limit state, a strength increasing coefficient with a value of $1.5\left(\gamma_{\mathrm{F}}\right)$ for all loads and a strength reduction coefficient $\left(\gamma_{M}\right)$ of the material, which is $\gamma_{M}=1.1$ in the case of steel and $\gamma_{M}=1.3$ for wood. With these figures, the load to apply in the case of a test on a steel element is $\mathrm{F}_{\mathrm{H}}=0.30 \cdot 1.5 \cdot 1.1=0.5 \mathrm{kN}$, while in the case of a wooden element, it is $\mathrm{F}_{\mathrm{H}}=0.30 \cdot 1.5 \cdot 1.3=0.6 \mathrm{kN}$.

The deflection should be no greater than $55 \mathrm{~mm}$, in order to satisfy the SLS, when a single horizontal load of $\mathrm{F}_{\mathrm{T} 1}=0.30 \mathrm{kN}$ is applied to the system, at its most unfavorable point.

It is specified that the guardrails should withstand a single gravitational load of $\mathrm{F}_{\mathrm{D}}=1.25 \mathrm{kN}$ in order to test an accidental load. This load should be applied at the most unfavorable position of the TEPS, within a sector inclined at $\pm 10^{\circ}$ slope in relation to the vertical plane.

The coefficients of increasing and strength reduction of the material take a unitary value for the evaluation in relation to the SLS and AL.

Figure 2 shows the set up for the deflection tests on the upper guardrail of system S2.

\subsection{Impact tests}

TEPS, formed of vertical metallic posts and tubular metallic rails, were subjected to a dynamic test with energy of $180 \mathrm{~J}$. The tests were performed by impacting a sphericonic ball with the composition and geometry specified in standard UNE-EN-596

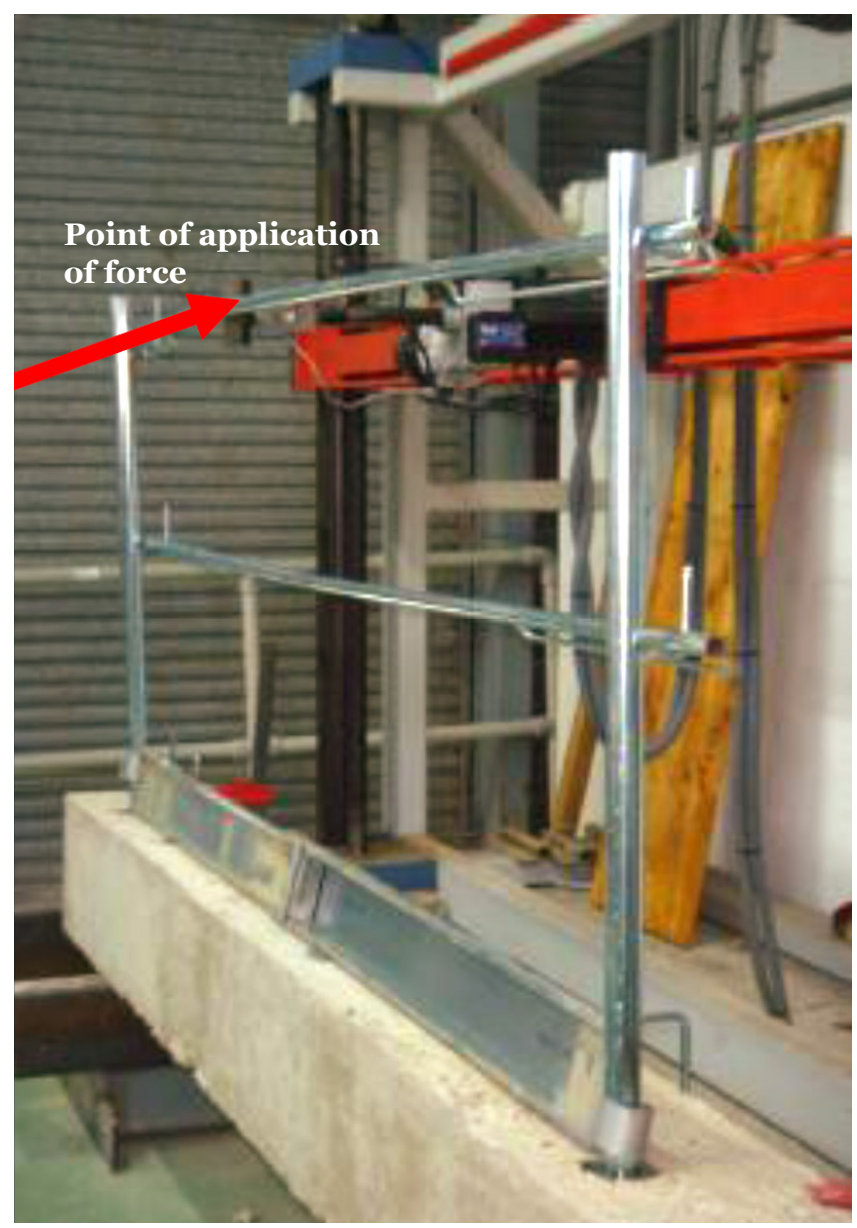

Figure 2. Deflection test on the upper guardrail of system S2. 
(28) from the necessary height, so that the energy of the impact would be equal to $180 \mathrm{~J}(180 \mathrm{~J} / 500 \mathrm{~N}=0.36 \mathrm{~m})$ (Figure 3).

The impacts occurred by hitting the ball against the central section of the main rails of the 7 systems and at the upper ends of the two vertical posts.

After the impact, the elements were visually checked to detect any possible buckling or breakage and were placed on a table to measure any permanent deformation.

Two vertical posts identical to those subjected to the impact were tested under static horizontal load applied at their upper ends to obtain their load-displacement diagram. During the test, the vertical posts were anchored with a PVC tube to a concrete beam, in a similar way to the anchor existing at the time of the dynamic impact.

\section{RESULTS OBTAINED}

\subsection{Static tests}

Table 2 shows the results obtained in the deflection and resistance tests on the systems and vertical posts under study when the loads were applied to the central section of the main guardrail and the upper end of the vertical posts.

The accidental load was evaluated at two different points on the guardrail: the central section where the flexural moment is at a maximum and a section very close to the support, where the shear stress is at a maximum.

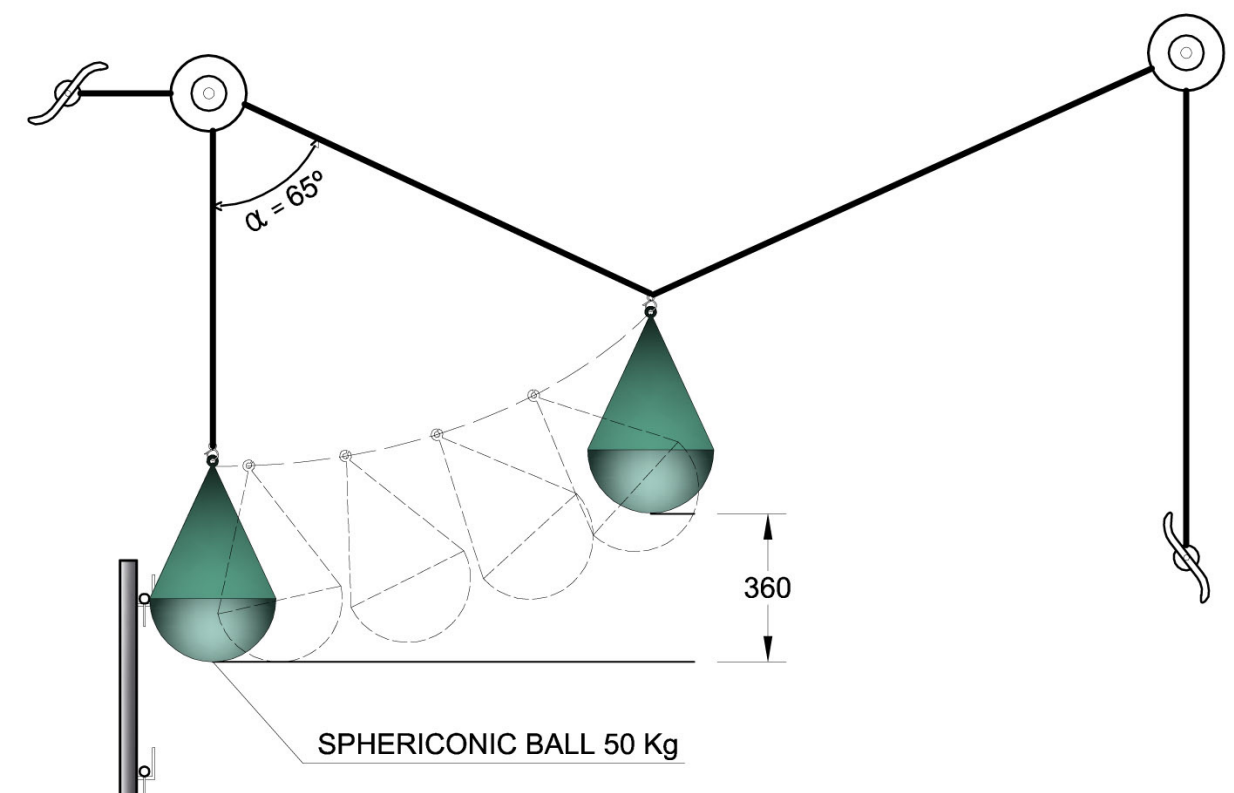

ANCHOR: PVC CARTRIDGE

EMBEDDED IN CONCRETE
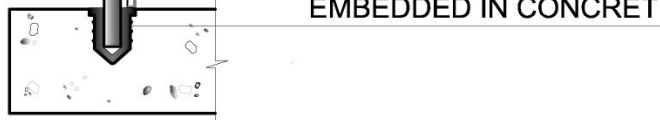

All dimensions in $\mathrm{mm}$

Figure 3. Impact test at $\mathrm{E}=180 \mathrm{~J}$.

Table 2. Results of the bending and resistance tests.

\begin{tabular}{|c|c|c|c|c|c|c|c|}
\hline \multirow{3}{*}{ ELEMENT } & \multirow{3}{*}{ SYSTEM } & \multicolumn{6}{|c|}{ TEST } \\
\hline & & \multicolumn{2}{|c|}{ DEFLECTION } & \multicolumn{4}{|c|}{ RESISTANCE } \\
\hline & & $F_{T}(k N)$ & $\delta(\mathrm{mm})$ & $F_{H}(k N)$ & $\delta_{\text {máx }}(\mathrm{mm})$ & $\delta_{\text {res }}(\mathrm{mm})$ & $R_{u}(k N)$ \\
\hline \multirow{2}{*}{ Steel rail } & $\mathrm{S} 1$ & 0.30 & 66.67 & 0.50 & 138.24 & 30.27 & $\mathbf{0 . 5 7}$ \\
\hline & $\mathrm{S} 2$ & 0.30 & 27.81 & 0.50 & 47.76 & 1.31 & $>0.60$ \\
\hline \multirow{5}{*}{ Wood rail } & $\mathrm{S}_{3}$ & 0.30 & 93.69 & 0.60 & 202.98 & 16.65 & $>0.72$ \\
\hline & $\mathrm{S}_{4}$ & 0.30 & 101.69 & 0.60 & 227.98 & 15.23 & $>0.72$ \\
\hline & $\mathrm{S}_{5}$ & 0.30 & 39.69 & 0.60 & 81.98 & 2.00 & $>0.72$ \\
\hline & S6 & 0.30 & 47.69 & 0.60 & 98.98 & 3.06 & $>0.72$ \\
\hline & S7 & 0.30 & $55 \cdot 54$ & 0.60 & 111.83 & 10.06 & $>0.72$ \\
\hline vertical posts & $\mathrm{P} 1$ & 0.30 & 20.98 & 0.50 & 28.62 & 1.60 & $>0.60$ \\
\hline
\end{tabular}

$\mathrm{F}_{\mathrm{T}}$ : Load applied in the deflection test (SLS). $\delta$ : Displacement of the system. $\mathrm{F}_{\mathrm{H}}$ : Load applied in the resistance test (ELU). $\mathrm{R}_{\mathrm{u}}$ : Load applied in the test of ultimate resistance. $\delta_{\max }:$ Maximum displacement of the system. $\delta_{\text {res }}:$ Residual displacement after application of the maximum load. 
The values marked in bold in Table 2 indicate non-compliance with the requirements in standard EN 13374.

In Figures 4 and 5, the results corresponding to the deflection and strength tests are shown when the load is applied to the central point of the main guardrail.
Figure 6 shows the results of the deflection and resistance tests on vertical post P1 when the load was applied to its upper end.

From among the seven systems that were tested, only system 1 failed to pass the accidental load test.

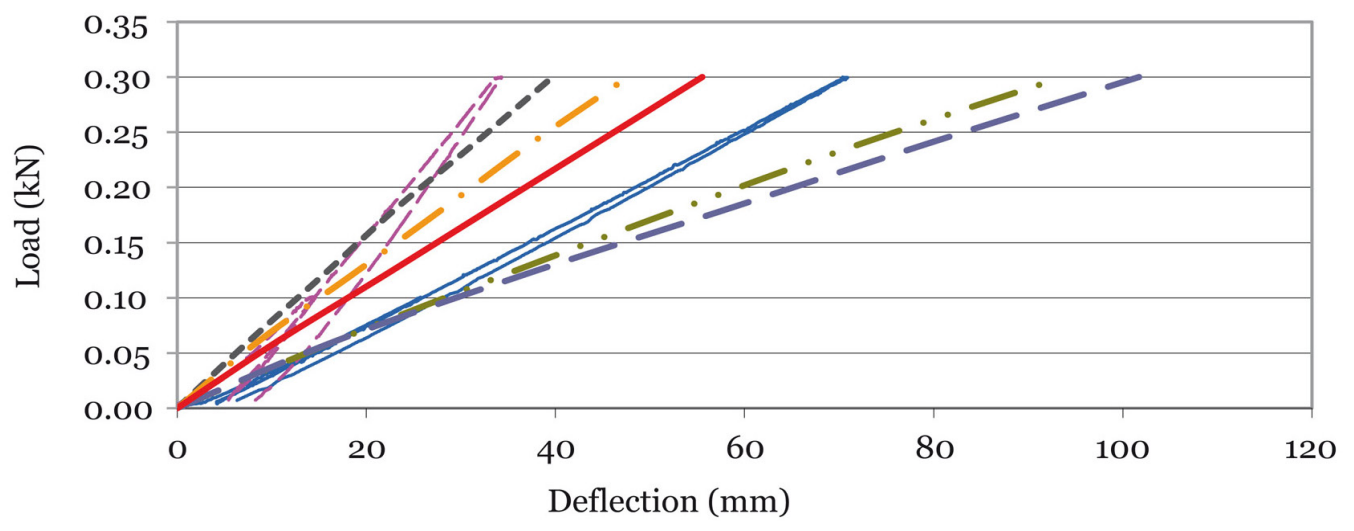

$$
\longrightarrow \mathrm{S}_{1}---\mathrm{S}_{2} \longrightarrow \mathrm{S}_{3} \longrightarrow-\mathrm{S}_{4}----\mathrm{S}_{5} \longrightarrow \mathrm{S}_{6} \quad \mathrm{~S}_{7}
$$

Figure 4. Results of the deflection test. Load applied to the central section of the main guardrail.

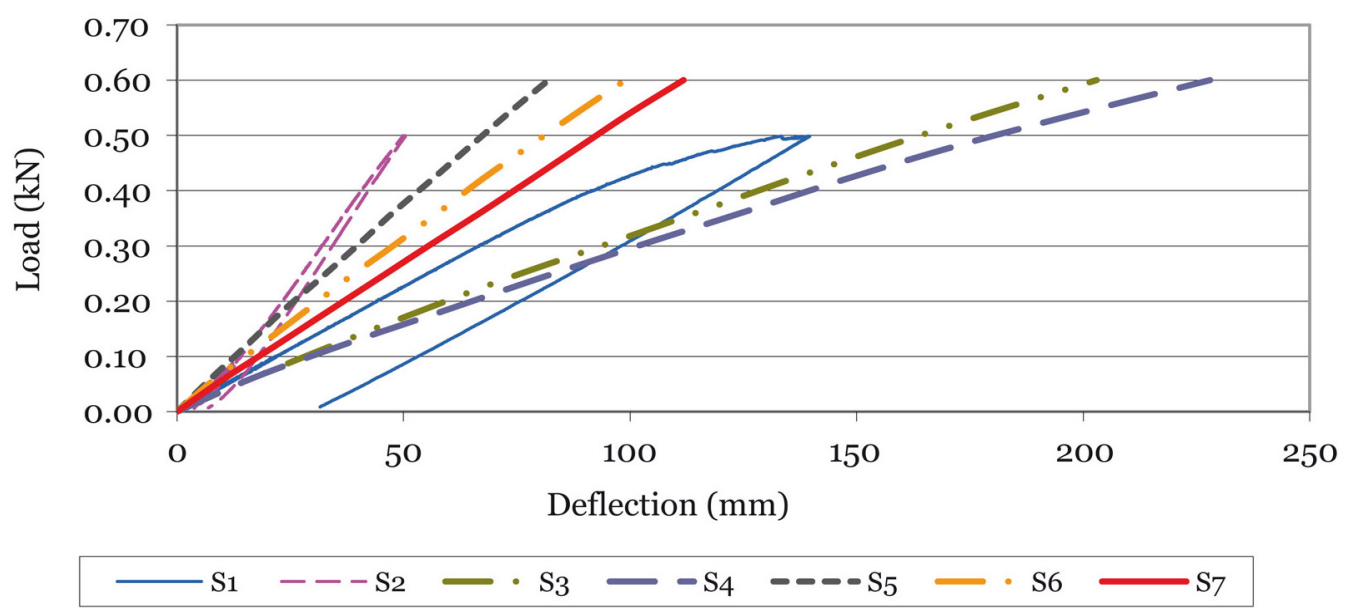

Figure 5. Results of resistance test. Load applied to the central section of the main guardrail.

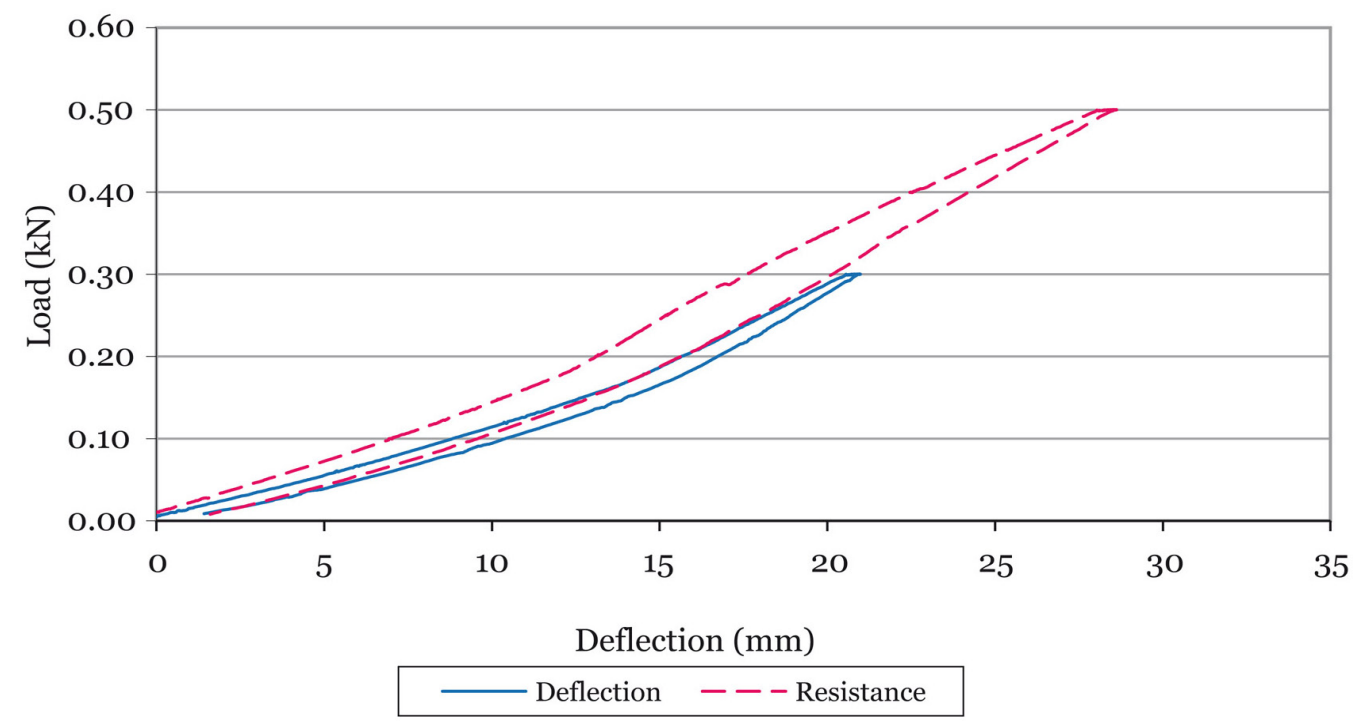

Figure 6. Results of the deflection and resistance tests. Load applied to the upper section of the vertical post. 


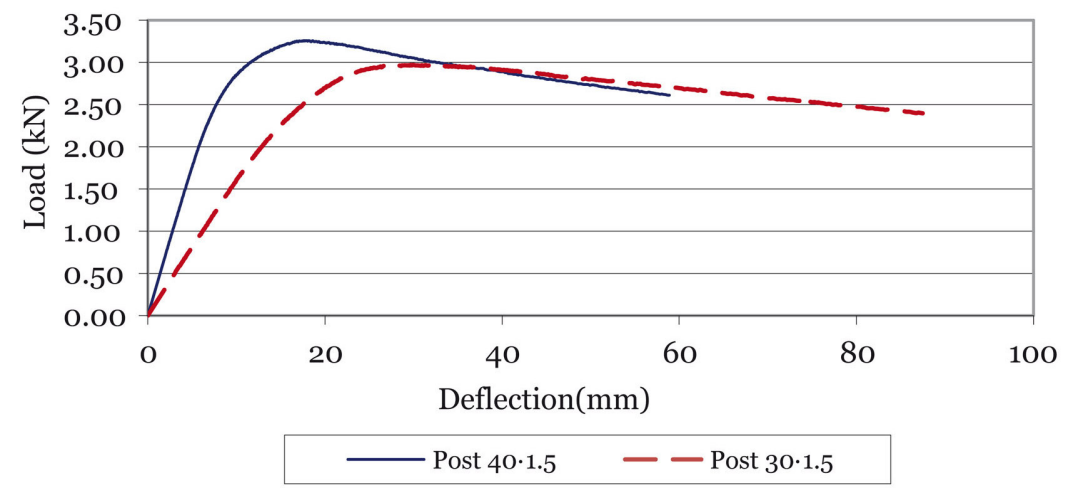

Figure 7. Load-deflection diagrams of the vertical steel posts applying increasing loads at their upper ends.

Figure 7 shows the load-deflection diagrams obtained from vertical posts $\mathrm{P}_{1}$ and $\mathrm{P}_{2}$ when increasing horizontal static loads were applied at their upper ends.

\subsection{Dynamic tests with impact load}

Even though the seven systems and the two vertical posts that were tested with an impact of $\mathrm{E}=180 \mathrm{~J}$ were able to withstand the sphericonic ball and resist an impact with that energy, the structural response of the different systems and elements is very different.

The principal guardrail of system S1, after the impact (Figure 8), experienced plastic deformations following which its geometry as indicated in Figure 9, had an excess deflection of $115.01 \mathrm{~mm}$, which meant an $11^{\circ}$ rotation in the plastic hinge.

None of the elements (main rails and vertical posts) of the other systems underwent any plastic deformations, when the impact centered on the main guardrail, and they recovered from each deformation that occurred at the time of the impact.

When the impact of $\mathrm{E}=180 \mathrm{~J}$ occurred at the upper end of vertical post $\mathrm{P} 1$, the pole underwent plastic deformation at the height of its attachment to the structure, having a residual deflection of $61.05 \mathrm{~mm}$ and a permanently bent angle with regard to the vertical of $3 \cdot 5^{\circ}$. In the case of post $\mathrm{P} 2$, the permanent deformations were larger, leaving a residual deflection of $104.53 \mathrm{~mm}$, which meant a rotated angle of $6^{\circ}$. Both posts withstood the ball at the time of its impact (Figures 10 and 11).

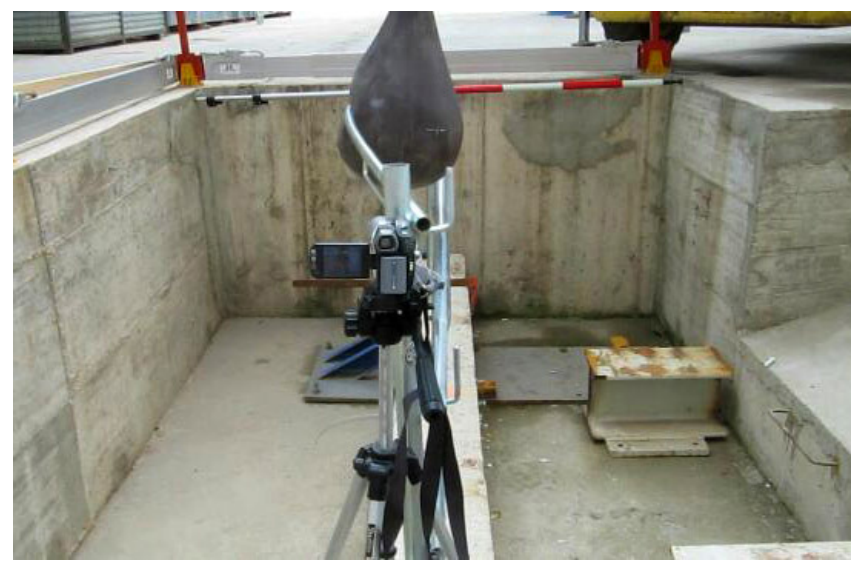

Figure 8. Maximum deflection of the $\mathrm{S} 1$ guardrail at the time of impact.

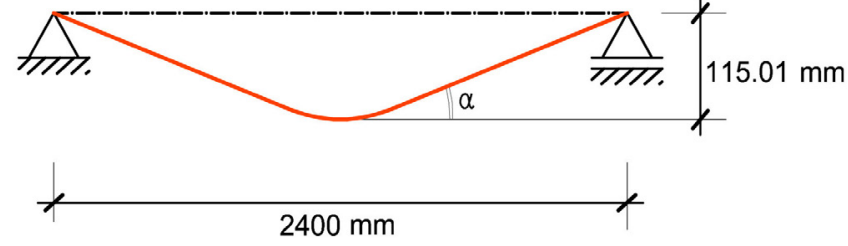

Figure 9. State of $\mathrm{S} 1$ guardrail after the impact.

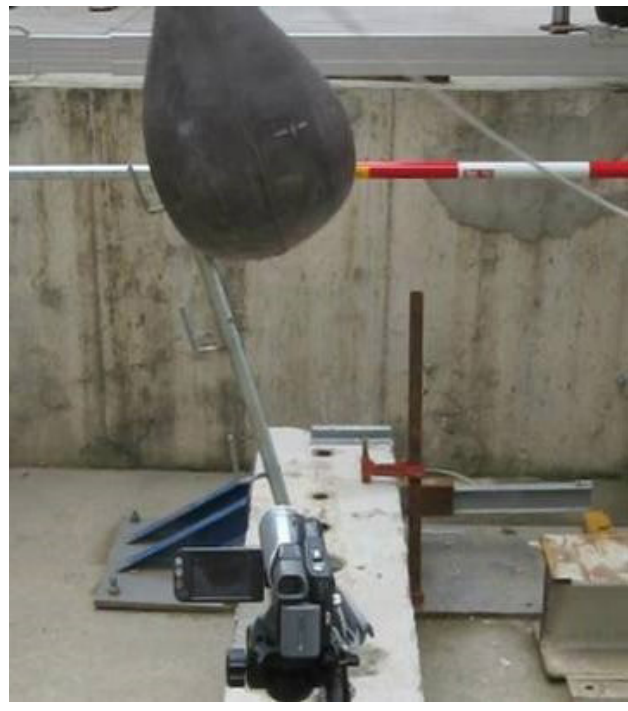

Figure 10. Maximum deflections produced in vertical posts $\mathrm{P} 1$ and $\mathrm{P} 2$ following the impact.

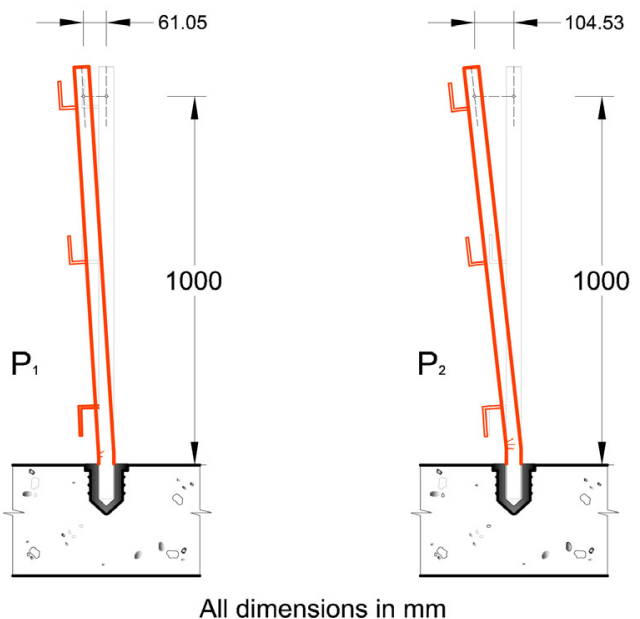

Figure 11. Permanent movements of vertical posts $\mathrm{P} 1$ and P2 following the impact. 


\section{ANALYSIS AND DISCUSSION}

\subsection{Static tests}

The results in Table 2 show that only systems 2 and 5 meet the requirements specified in standard EN 13374 for experimental evaluation. System 1, habitually used on construction sites in Spain, neither satisfies the deflection requirements nor satisfies the resistance requirements. Systems 3, 4, 6 and 7 fail to pass the deflection test. Only System 1 fails to pass the accidental load test.

It may be confirmed from Figure 4 that the behavior during the deflection test on the 7 systems is practically elastic and linear. The differences in guardrail rigidity are evident from the different slopes of the respective diagrams.

Figure 5 once again highlights the different rigidities of the three systems. In system 1 , the diagram is approximately linear up until a load of $0.40 \mathrm{kN}$, from that point the linearity is lost and the movements grow more rapidly than the forces, slowly losing system rigidity, as a consequence of the plastic deformation that is occurring in the system. When reaching maximum loading and unloading, the unloading takes place along a parallel straight line to the application of the loads and a residual deflection is left of approximately $30 \mathrm{~mm}$ $(30.07 \mathrm{~mm})$. In this case, the system resists the maximum test load, but does not comply with the other two requirements of the standard: residual deflection is $10 \%$ above the instantaneous maximum on the main and intermediary guardrails and ultimate resistance $(0.57 \mathrm{kN})$ is not more than 1.2 times the maximum test load of $0.60 \mathrm{kN}$, (Table 2 and Figure 5).

The behavior of systems 2-7 is linear, with practically no observable deformation remaining. The three points indicated in the standard for satisfying the resistance requirement were all satisfied (Table 2 and Figure 5).

The load-deflection curve corresponding the deflection test for post P1 (Figure 6) initially showed anomalous behavior, as a consequence of non-linear deformation of the PVC tube when the load was applied, which produces a non-linear graph reflecting rigidity under loading. The behavior is linear, once approximately half the test load has been applied. Unloading takes place in an elastic way, very approximately in line with the curve that reflects the load. A movement below the limit permitted by the standard was obtained.

In the load-deflection graph corresponding to post P1 during the resistance test (Figure 6), anomalous behavior was once again evident as the load increased, with an increase in the rigidity of the system, caused by deformations between the PVC tube embedded in the concrete beam and the metallic vertical post. When these deformations ended (at approximately $0.20 \mathrm{kN}$ ), behaviour corresponded to the rigidity of the post. The maximum test load having been reached, unloading occurred in a similar way to loading, which means that the deformations in the PVC tube recovered and the behavior of the vertical post was elastic. The vertical post passed the resistance test.

\subsection{Impact tests}

The test results showed that all the systems were able to withstand a sphericonic ball with an energy impact of $180 \mathrm{~J}$.

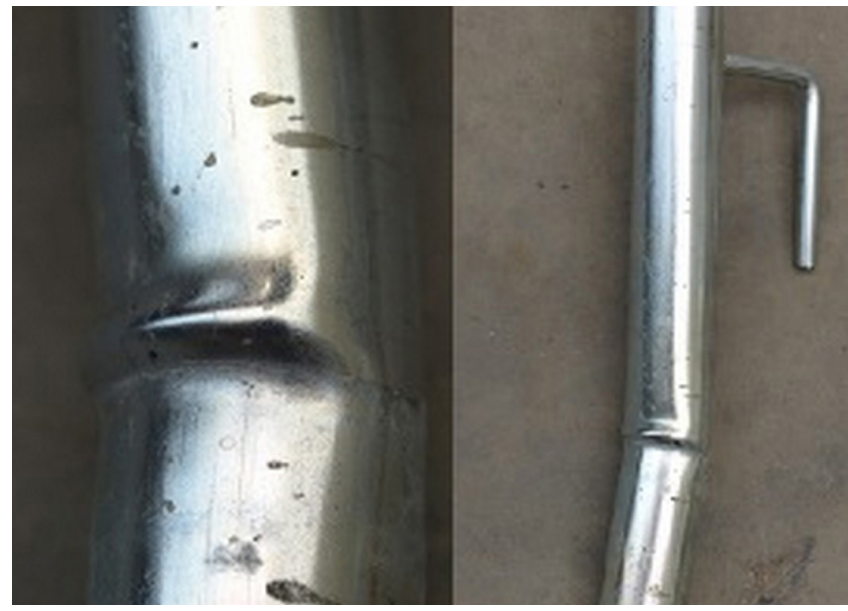

Figure 12. Reduction of the resistance moment of a vertical post due to buckling.

When the impact occurred at the centre of the main guardrail, plastic deformations only appeared in the central section of the railing of system $\mathrm{S} 1$. The other systems recovered from the deformations produced during the impact.

Analysis of the load-deflection diagrams of the vertical posts 40·1.5 and $30 \cdot 1.5$ in Figure 11 reveal a more rigid behavior up until the maximum test load of the vertical post 40-1.5. Having reached the maximum test load, both vertical posts underwent a drop in resistance until the end of the test. It should be noted that there is no period of plastic yield after reaching the maximum load, as might be expected due to the behavior of the steel. The difference is because when the maximum test load is reached and the piece continues to be deformed, a modification in the geometry of the section under greatest pressure takes place, leading to local buckling and reducing the resistant moment and the inertia of the section. Figure 12 shows the section under the greatest stress of a tubular section subjected to a flexural test. It may be seen that local buckling in the section implies a reduction in its resistant moment.

In the cases under study, the classification found in EC-3 (29) of the class 1 sections is unsafe, as the tests results show.

Some documents (26) indicate that a TEPS is valid when it is able to absorb energy of $180 \mathrm{~J}$, appending an analytic evaluation procedure that uses an elastoplastic diagram to represent the behavior of the system. The above results show that the use of the elastoplastic diagram is not valid, because the system is unable to develop sufficient plastic deformation.

Table 3 shows the maximum load reached in the Bending test $\left(\mathrm{P}_{\max }\right)$ test, the maximum deflection reached during the test $\left(\delta_{\max }^{\max }\right)$, absorbed energy up until the elastic and maximum loads are reached ( $\mathrm{E}_{\mathrm{e}}$ and $\left.\mathrm{E}_{1}\right)$, and total energy absorbed throughout the entire test, for vertical posts P1 and P2 $\left(\mathrm{E}_{\mathrm{T}}\right)$.

Table 3. Results for vertical posts $\mathrm{P}_{1}(40 \cdot 1.5)$ and $\mathrm{P}_{2}(30 \cdot 1.5)$ in a static bending test.

\begin{tabular}{|c|c|c|c|c|c|}
\hline & $P_{\text {max }}(k N)$ & $\delta_{\max }(\mathrm{mm})$ & $E_{e}(J)$ & $E_{1}(J)$ & $\mathrm{E}_{\mathrm{T}}(\mathrm{J})$ \\
\hline P1 $(40 \cdot 1.5)$ & 3.26 & 58.88 & 7 & 40 & 160 \\
\hline P2 (30-1.5) & 2.97 & 87.48 & 17 & 58 & 214 \\
\hline
\end{tabular}


It can be experimentally confirmed that both vertical posts were able to withstand the impact and what is more, the displacements obtained after the impact were very similar to the maximum displacements obtained during the static test (Table 3 and Figure 10).

However, it should be noted that the energy at the time of the impact was $180 \mathrm{~J}$, although it was not only the vertical post that absorbed that energy with its deformation, as an important part was absorbed by the ball itself, due to its own deformation. The local deformation of the ball may be seen in Figure 13 once the impact has occurred. In fact, when the systems or elements pass the test, it may be stated that they resist the impact energy of $180 \mathrm{~J}$, but it may not be said that they absorb $180 \mathrm{~J}$ of energy, because part of the energy of the impact is absorbed by the ball that causes the impact.

The values in Table 3 for absorbed energy in the elastic period and absorbed energy up until the maximum test load are very much below $180 \mathrm{~J}$, which highlights that plastic deformation would have to take place practically up until the failure of the piece to be able to absorb an impact of $180 \mathrm{~J}$.

The experimental results from systems $\mathrm{S}_{3}-\mathrm{S} 7$ show that the systems pass the test in all cases with an impact energy of $\mathrm{E}=180 \mathrm{~J}$ and, in addition, neither breakage nor plastic deformation takes place in any of their constituent elements. Even systems made up of boards with a thickness of $22 \mathrm{~mm}$ with defects (system $\mathrm{S} 4$ ) were able to resist the impact.

When these systems are evaluated under static loads, the results show that systems $\mathrm{S}_{3}$ and $\mathrm{S}_{4}$ (boards with thicknesses of $22 \mathrm{~mm}$ of any quality) and S6 and S7 (Boards with a thickness of $27 \mathrm{~mm}$ with a visual classification of ME2 or Defect) are unable to fulfill the deflection requirement, obtaining deflection values that, in the case of the board with a thickness of $22 \mathrm{~mm}$, were almost double the maximum permitted levels. The tests undertaken on the systems using boards with a thickness of $27 \mathrm{~mm}$ fulfill the static load requirements of

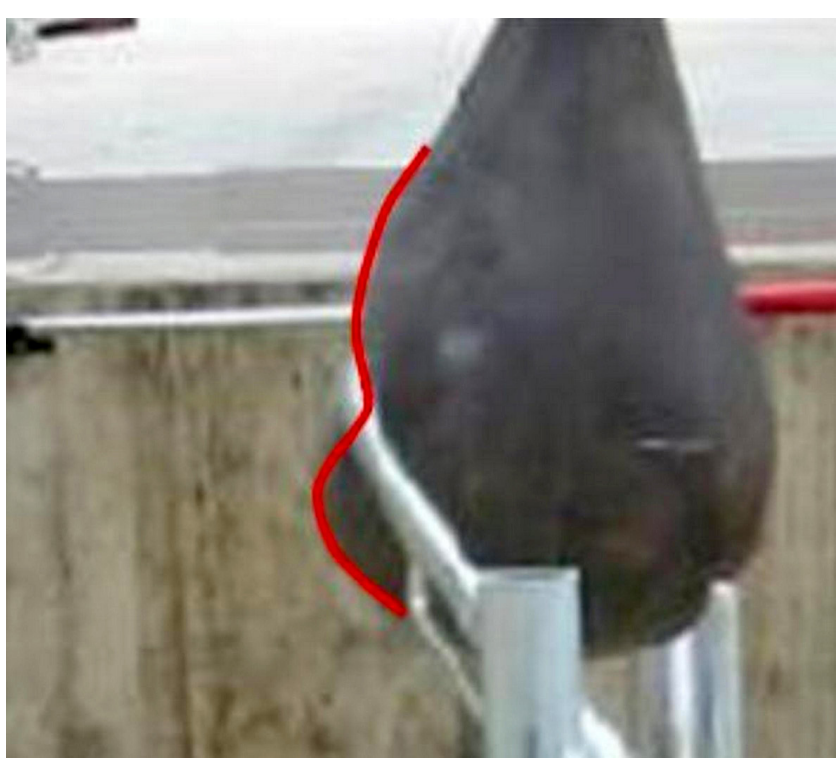

Figure 13. Deformation produced in the ball after an impact of $180 \mathrm{~J}$ on a TEPS. standard EN 13374, but the deflection obtained in the bending test is very close to the permitted deflection value of the standard.

These results allow us to affirm that the static load test defined by standard EN 13374 is more demanding than the energy impact of $180 \mathrm{~J}$, when the systems are made up of tubular steel rails or wooden boards supported on metallic vertical posts with a separation between the vertical posts of $2400 \mathrm{~mm}$.

When the impact of the sphericonic ball or the balls of pellets takes place, the object that impacts absorbs a large part of the impact energy rather than the resistant structure. The photograph in Figure 13 shows deformation of the sphericonic ball during the impact and, when the balls of pellets impact, they are partially deformed adopting the form of the board that they hit.

\section{CONCLUSIONS}

The TEPS that have a separation of $2400 \mathrm{~mm}$ between the vertical posts, which are made of circular tubular steel with a section of $40 \cdot 1.5$ in vertical posts, and a section of $25 \cdot 1.5$ in guardrails, fail to comply with any of the requirements (bending tests, resistance and accidental load) in standard EN 13374. In Spain, systems with these characteristics or even of smaller sections in both the rails and vertical posts are very common. All the requirements of the standard were satisfied, when the tests were performed on circular tubular steel rails with a section of $40 \cdot 1.5$.

TEPS that have a separation between the vertical posts of $2400 \mathrm{~mm}$, made with circular tubular steel vertical posts with a section of $40 \cdot 1.5$ and pine-wood rails with a rectangular section of $150 \times 22 \mathrm{~mm}$ were unable to satisfy the deflection requirement of standard EN 13374. When the thickness of the board was increased to $27 \mathrm{~mm}$, the boards with a visual classification of ME1 and ME2 were able to satisfy the requirements of the standard, and the boards with a visual defect classification failed the tests, experiencing deflections above the permitted levels. In Spain, the most commonly used wood in the manufacture of guardrails has the visual defect classification, such that spans between the vertical posts of $2400 \mathrm{~mm}$ and with a cross-section of $150 \times 27$ or less would not satisfy the requirements of the standard.

The results obtained from TEPS on steel and wooden guardrails have shown that the systems are able to withstand the impactor, defined by standard EN 596, when it impacts with an energy of $180 \mathrm{~J}$, but in some cases they fail to satisfy the static load requirements established by standard $\mathrm{EN} \mathrm{13374,} \mathrm{in} \mathrm{order} \mathrm{to} \mathrm{be}$ evaluated as class A. For the systems under study, it may be understood that the static evaluation of standard EN 13374 is more demanding than the energy impact test of $180 \mathrm{~J}$.

An important role is played in the performance of the impact tests on TEPS by the composition of the impactor. In the case of an impact with a sphericonic ball, defined by standard EN 596, an important part of the impact energy is absorbed by the ball. The TEPS is able to resist the impact but does not absorb $180 \mathrm{~J}$, as is evident from the static tests conducted on the vertical posts. It may be confirmed from the deflection of the vertical posts in the impact test that the energy the vertical posts actually absorb is below $180 \mathrm{~J}$. The authors believe that the impactor 
type specified by the standard absorb less energy than it absorb the human body. For this reason the TEPS are more loaded in these tests that in the case of real impacts. It may be appropriate to modify the type of impactor using objects and materials that best simulate the impact of a person. Thus results that are more in line with reality would be obtained.
Among the structural elements studied in this work, the classification of tubular sections of steel as indicated in EC-3 verges on the side of unsafety. The tubular steel guardrails with sections of $25 \cdot 1.5,40 \cdot 1.5$ and $30 \cdot 1.5$ underwent no significant plastic deformation when buckling of their sections occurred.

\section{REFERENCES}

(1) Ministerio de Trabajo y Asuntos Sociales, Instituto Nacional de Seguridad e Higiene en el Trabajo. (2007). VI Encuesta Nacional de condiciones de trabajo. http://encuestasnacionales.oect.es/.

(2) OSHA. (1990). Analysis of Construction Fatalities. The OSHA Data Base 1985-1989. Washington, D.C.: OSHA, U.S. Department of labor.

(3) OSHA. (1998). Fall protection Systems criteria and practices, Part 1926. Subpart M CFR 1926.5O2. Washington, D.C.: Occupational Safety \& Health Administration OSHA, US Department of Labor.

(4) Sa, J. (2005). An investigation of fall protection systems in the roofing industry (Thesis). Whitewater, USA: The University of Wisconsin-Whitewater.

(5) Ministerio de la Presidencia. (1997). Real Decreto 1627/1997, de 24 de octubre, por el que se establecen disposiciones mínimas de seguridad y salud en las obras de construcción. Anexo IV - Parte C. Boletín Oficial del Estado, nº 256. Madrid, Spain.

(6) Ministerio de Empleo y Seguridad Social. (2012). V Convenio colectivo del sector de la construcción. Libro Segundo. Título IV. Resolución de 28 de febrero de 2012. Boletín Oficial del Estado, $\mathrm{n}^{0}$ 64. Madrid, Spain.

(7) Gouvernement du Québec. (2001). S-2.1, r.6, 2001: Québec Safety Code for the Construction Industry. Québec: Les Publications du Québec - Gouvernement du Québec.

(8) Johnson, H., Singh, A. (1998). Fall protection analysis for workers on residential roofs. Journal of Construction Engineering and Management, 124 (5): 418-428, doi: http://dx.doi.org/10.1061/(ASCE)0733-9364(1998)124:5(418).

(9) Personick, M.E. (1990). Profiles in safety and health: roofing and sheet metal work. Monthly Labor Review of Bureau of Labor Statistics, 113: 27-32.

(10) Suruda, A., Fosbroke, D., Braddee, R. (1995). Fatal work-related falls from roofs. Journal of Safety Research, 26(1): 1-8, doi: http://dx.doi.org/10.1016/0022-4375(94)ooo26-3.

(11) U.S. Department of Labor - Occupational Safety \& Health Administration OSHA. (2012). http://www.osha.gov/SLTC/ fallprotection/index.html.

(12) González, M.N., Cobo, A., Fuente, J.V., Bresó, S., Lozano, C. (2011). Comportamiento bajo cargas estáticas de sistemas provisionales de protección de borde realizados con elementos de acero. Informes de la Construcción, 63(521): 57-67, doi: http://dx.doi.org/10.3989/ic.09.070.

(13) Lan, A., Daigle, R. (2009). Development and validation of a method for evaluating temporary wooden guardrails built and installed on construction sites. Safety Science, 47(2): 215-226, doi: http://dx.doi.org/10.1016/j.ssci.2008.03.001.

(14) Bobick, T.G., McKenzie Jr, E.A., Kau, T.Y. (2010). Evaluation of guardrail systems for preventing falls through roof and floor holes. Journal of Safety Research, 41(3): 203-211, doi: http://dx.doi.org/10.1016/j.jsr.2010.02.008.

(15) González-García, M.N. (2010). Consideraciones respecto a los sistemas provisionales de protección de borde (Tesis Doctoral). Madrid: Universidad Politécnica de Madrid.

(16) González, M.N., Cobo, A., Lozano, C., Bresó, S. (2013). Comportamiento de Sistemas Provisionales de Protección de Borde de polietileno de alta densidad frente a cargas estáticas y de impacto. Materiales de Construcción, 63(310): 283296, doi: http://dx.doi.org/10.3989/mc.2012.07111.

(17) Pomares, J.C., Irles, R., Segovia, E.G., Boixader, D. (2013). Barandillas de protección personal con solicitación dinámica. Informes de la Construcción, 65(530): 241-251, doi: http://dx.doi.org/10.3989/ic.11.040.

(18) González, M.N.; Cobo, A.; Fuente, J.V. (2013). Obtención de modelos de cálculo de sistemas provisionales de protección de borde mediante la técnica de Análisis Modal Operacional. Informes de la Construcción, 65(529): 99-106, doi: http:// dx.doi.org/10.3989/ic.11.133.

(19) CEN. (2013). EN 13374 - Temporary edge protection system. Product specification, test methods. European Committee for Standardization.

(20) ASTM. (1987). E 985-87 - Standard Specification for Permanent Metal Railing Systems and Rail for Buildings. Philadelphia, PA.: American Society for Testing and Materials ASTM.

(21) eLCOSH. (2008). Guiones orientadores para la protección anticaída de alturas. Biblioteca Electrónica de Salud y Seguridad Ocupacional en la Construcción. http://www.elcosh.org/document/2264/dooo052/Guiones\%2Borientadores \%2Bpara\%2Bla\%2Bprotecci\%25C3\%25B3n\%2Bantica\%25C3\%25ADda\%2Bde\%2Balturas.html?show_text=1.

(22) OPPBTP. (1993). Mémo-practique B1 F 01 93. Protections Collectives pour empecher les chutes d'hauteur dans le bâtiment et les travaux public. France: Organisme Professionnel de Prévention du Bâtiment et des Travaux Publics OPPBTP.

(23) AS. (1992). Fixed platforms, walkways, stairways and ladders - Design, construction and installation. Standards Association of Australia.

(24) Lan, A., Arteau, J., Daigle, R. (2005). Développement et validation d'une méthode d'évaluation des garde-corps fabriqués et installés à pied d'œuvre sur les chantiers. 1 Introduction. Problématique de santé et sécurité du travail. Rapport R-415. Québec: IRST. 
(25) Jacmin, M., Mayer, A. (1984). Écran garde-corps- Protection contre les chutes de grande hauteur pour les travaux d'étanchéité en toiture. ED 1180. Paris, France : Institut National de Recherche et de Sécurité (INRS).

(26) AFNOR. (2010). NF P 93-355 - Equipements de chantier. Protection périphérique temporaire pour travaux d'étanchéité en toiture. Spécification du produit, méthode d'essai Protection temporaire. Paris, France: Association française de normalization (AFNOR).

(27) AENOR. (2007). UNE-EN 56544 - Clasificación visual de la madera aserrada para uso estructural. Madera de coníferas. Asociación Española de Normalización (AENOR).

(28) AENOR. (1997). UNE-EN 596 - Estructuras de madera. Métodos de ensayo. Ensayos de choque por cuerpo blando sobre muros entramados de madera. Asociación Española de Normalización (AENOR).

(29) AENOR. (2008). EN 1993-1-1 - Eurocódigo 3. Proyecto de estructuras de acero. Parte 1-1: Reglas generales y reglas para edificación. Asociación Española de Normalización (AENOR). 